\title{
NATURAL HYBRIDIZATION BETWEEN ELYMUS REPENS AND ELYMUS HISPIDUS ASSESSED BY AFLP ANALYSIS
}

\author{
Magdalena SzCZePaniaK ${ }^{1}$, ElżBIETA CieŚlaK ${ }^{1}$, Piotr T. BednareK ${ }^{2}$ \\ ${ }^{1}$ W. Szafer Institute of Botany, Polish Academy of Sciences, \\ Department of Vascular Plants Systematics \\ ul. Lubicz 42, 31-512 Kraków, Poland \\ e-mail: Magdalena.Szczepaniak@ib-pan.krakow.pl \\ 2 Plant Breeding and Acclimatization Institute, \\ Department of Plant Biochemistry and Physiology \\ 05-870 Błonie, Radzików, Poland
}

(Received: June 11, 2006. Accepted: September 27, 2006)

\begin{abstract}
Hybrid speciation within the genus Elymus is analyzed and discussed. The supposed hybrid origin of Elymus $\times$ mucronatus between Elymus repens and Elymus hispidus was tested. In this aim, pollen viability and AFLP variation of putative progenitors and progenies from two natural populations were studied. Pollen fertility of hybrids ranging from 0 to $91.95 \%$ (average 59.50\%) indicates the occurrence of F1 hybrids and backcross hybrids. Seven EcoRI/MseI AFLP primer combinations generated a total of 477 AFLP fragments (300 polymorphic) for 48 parental and hybrid individuals. UPGMA and principal coordinates analysis of the AFLP data set show that hybrids are closer to E. hispidus than to E. repens and suggest unidirectional introgression towards E. hispidus. AFLP fragments of the hybrid taxon were additively inherited from the parental species and no hybrid-specific bands were identified. AFLP analysis validates the hybrid status of E. Xmucronatus. Populations in which E. repens, E. hispidus and their hybrids co-occur still progress from early hybridization stages of F1 hybrids to an advanced hybridization stage of a well-established hybrid swarm. E. ×mucronatus is potentially self-sustaining by predominant vegetative reproduction by rhizomes and partial fertility leading to the development of mature seeds. We propose to consider Elymus $\times$ mucronatus as a new species of hybrid origin in the Polish flora
\end{abstract}

KEY WORDS: AFLP, genetic variation, pollen fertility, unidirectional introgression, Elymus repens, Elymus hispidus, Elymus $\times$ mucronatus.

\section{INTRODUCTION}

Hybridization is a well known natural phenomenon and an important mechanism of evolution in plants (Rieseberg 1995; Arnold 1997; Hegarty and Hiscock 2005; Wissemann 2005). However, the frequency of spontaneous hybridization is not universal and differs between plant families and genera, as demonstrated in multiple biosystematic floras (Ellstrand et al. 1996). In natural habitats, many spontaneous hybrids have been found in the tribe Triticeae Dumort., especially between polyploidy species (Nelson and Tyrl 1978; Salomon and Lu 1992; Assadi and Runemark 1995). Hybridization and subsequent introgression of genes of one species into the genomes of others can increase morphological variation of Triticeae species, and in particular of grasses belonging to the genus Elymus L. (Brown and Pratt 1960; Nelson and Tyrl 1978; Diaz et al. 1999).

Elymus repens (L.) Gould [Syn.: Agropyron repens (L.) P. Beauv., Elytrigia repens (L.) Desv. ex Nevski] is a cos- mopolitan species and occurs almost in the entire world (Hultén and Fries 1986). It is a species characterized by a high tolerance to environmental stress factors and grows in very diverse habitats from wet to strongly dry, and displays great inter- and intrapopulational morphological polymorphism (Prokudin 1982; Szczepaniak 2002a, 2003a; Szczepaniak et al. 2002). Three varieties (var. repens, var. aristatus and var. subulatus) differing mainly in the length of glume awns, lemma awns and the glume shape were distinguished within E. repens in Poland (Szczepaniak 2002b, 2003a).

Elymus hispidus (Opiz) Melderis [Syn.: Agropyron intermedium (Host) P. Beauv., Elytrigia intermedia (Host) Nevski] is included in the group of the Mediterraneo-IranoTuranian connective element and occurs in the area from Central Asia to Southern and Western Europe, reaching France and Spain (Tsvelev 1976; Melderis 1980). This perennial grass occurs in Poland primarily in xerothermic grasslands of the Festuco-Brometea Br.-Bl. et Tx. 1943 
class, which are confined to warm, sunny and dry hill slopes between fields and to steep escarpments of river valleys, composed of the calcareous or loess substratum (Szczepaniak 2001). Two subspecies (subsp. hispidus and subsp. barbulatus) or varieties (var. hispidus and var. villosus, respectively) are distinguished in the Polish flora on the basis of hairless or hairy glumes and lemmas (Szczepaniak 2002b, 2003b; Szczepaniak and Cieślak 2003).

Natural hybridization between Elymus repens and E. hispidus growing together in the same locality is probable. Two species of hybrid origin were originally and validly described as Agropyron ×mucronatum Opiz ex Bercht. (Berchtold and Opiz 1836) [Syn.: Elymus repens $\times$ E. hispidus var. hispidus] and Agropyron $\times$ tesquicolum Prokud. (Prokudin 1940) [Syn.: E. repens $\times$ E. hispidus var. villosus]. Prokudin and Druleva $(1971,1972)$ later described the same species as Elytrigia $\times$ mucronata (Opiz ex Bercht.) Prokudin, arisen by interspecific hybridization between Elytrigia repens and Elytrigia intermedia, and Elytrigia Xtesquicola (Czerniak.) Prokudin, a hybrid between Elytrigia repens and Elytrigia trichophora. The occurrence of hybridization among those species of Elytrigia has been suggested on the basis on morphological and anatomical intermediacy of some individuals found in the same habitat as their putative progenitors. Recent flow cytometric and karyological investigations have confirmed common natural hybridization in the Elytrigia repens $-E$. intermedia alliance (Mahelka et al. 2005). The genome size turned out to be a reliable marker for these taxa and hybrid delimitation.

Multivariate statistical analyses of intraspecific morphological variation of Elymus repens and E. hispidus clearly show intermediate individuals among those species that were defined as specimens of the hybrid origin species Ely- mus $\times$ mucronatus with two varieties: nvar. mucronatus [Syn.: E. repens $\times$ E. hispidus var. hispidus] and nvar. tesquicolus [Syn.: E. repens $\times$ E. hispidus var. villosus] (Szczepaniak 2003b). These varieties differ only in the degree of glume and lemma hairiness, and occur in the same habitats. Hybrid individuals are often clearly distinguished from their parental species mainly by the presence of ciliate leaf sheath margins, more or less truncate and very shortly mucronate glumes (like in E. hispidus), and gradually tapering awned lemmas (like in E. repens). Interestingly, there is a great morphological variation among the hybrids examined. This suggests that hybrid individuals may be a hybrid swarm or/and introgressant forms, and that advanced hybridization is taking place.

In the present work, the hypothesis that morphological intermediate individuals have derived from ancient and/or recent hybridization between Elymus repens and E. hispi$d u s$ was tested. For this purpose: (1) fertility of presumable hybrids was estimated, (2) AFLP analysis was used to assess the relationship and genetic distinction or its lack between the putative hybrids and their progenitors. The taxonomic status of the hybrids was established.

Molecular techniques have made the detection of hybridization increasingly easier. Allendorf et al. (2001) argue for advantages of genetic markers over morphological data to reveal hybrid individuals. The Amplified Fragment Length Polymorphism (AFLP) method (Vos. et al. 1995) has successfully been used to investigate the gene flow and genomic changes resulting from hybridization and introgression in polyploid taxa of the genus Achillea (Guo et al. 2005). Taxonomic distinctions of new species of hybrid origin, e.g., Cardamine xenriquei (Marhold et al. 2002), Mangifera ×odorata (Teo et al. 2002), and Sonneratia

TABLE 1. Sample size (N) and localities of Elymus repens, E. hispidus and E. ×mucronatus analyzed for AFLP.

\begin{tabular}{|c|c|c|c|c|c|}
\hline \multicolumn{2}{|c|}{ Populations } & \multirow[t]{2}{*}{$\mathrm{N}$} & \multirow[t]{2}{*}{ Localities } & \multirow[t]{2}{*}{ Position } & \multirow[t]{2}{*}{ Habitats } \\
\hline Elyn & & & & & \\
\hline $\begin{array}{l}\mathrm{R} 1 \\
\mathrm{R} 2\end{array}$ & $\begin{array}{l}\text { var. aristatus } \\
\text { var. repens }\end{array}$ & $\begin{array}{l}5 \\
5\end{array}$ & $\begin{array}{l}\text { Poland, Małopolska Upland, } \\
\text { Niecka Nidziańska Basin, } \\
\text { Smoniowice near Miechów }\end{array}$ & $\mathrm{N} 50^{\circ} 17^{\prime} \mathrm{E} 14^{\circ} 20^{\prime}$ & $\begin{array}{l}\text { Loess slope along road, } \\
\text { bordering with cultivation field }\end{array}$ \\
\hline \multicolumn{6}{|c|}{ Elymus hispidus } \\
\hline $\begin{array}{l}\mathrm{H} \\
\mathrm{B} \\
\mathrm{H} 3\end{array}$ & $\begin{array}{l}\text { var. hispidus } \\
\text { var. villosus } \\
\text { var. hispidus }\end{array}$ & $\begin{array}{l}5 \\
3 \\
4\end{array}$ & $\begin{array}{l}\text { Poland, Małopolska Upland, } \\
\text { Niecka Nidziańska Basin, } \\
\text { Smoniowice near Miechów }\end{array}$ & $\mathrm{N} 50^{\circ} 17^{\prime} \mathrm{E} 14^{\circ} 20^{\prime}$ & $\begin{array}{l}\text { Loess slope along road, } \\
\text { bordering with cultivation field }\end{array}$ \\
\hline \multicolumn{6}{|c|}{ Elymus $\times$ mucronatus } \\
\hline $\begin{array}{l}\text { M1 } \\
\text { M2 } \\
\text { Te }\end{array}$ & $\begin{array}{l}\text { nvar. mucronatus } \\
\text { nvar. mucronatus } \\
\text { nvar. tesquicolus }\end{array}$ & $\begin{array}{l}5 \\
5 \\
5\end{array}$ & $\begin{array}{l}\text { Poland, Małopolska Upland, } \\
\text { Niecka Nidziańska Basin, } \\
\text { Smoniowice near Miechów }\end{array}$ & $\mathrm{N} 50^{\circ} 17^{\prime} \mathrm{E} 14^{\circ} 20^{\prime}$ & $\begin{array}{l}\text { Loess slope along road, bordering } \\
\text { with cultivation field }\end{array}$ \\
\hline M3 & nvar. mucronatus & 4 & $\begin{array}{l}\text { Poland, Kielce-Sandomierz Upland, } \\
\text { Kielce }\end{array}$ & $\mathrm{N} 50^{\circ} 53^{\prime} \mathrm{E} 20^{\circ} 37^{\prime}$ & $\begin{array}{l}\text { Excavation of old quarry, on calcareous, } \\
\text { stony soil }\end{array}$ \\
\hline
\end{tabular}


$\times$ gulngai (Zhou et al. 2005) were revealed by AFLP markers. A combination of morphological and molecular approaches, including the AFLP method, helped to determine the degree of genetic distinctiveness, hybridization and clonality for some Potamogeton species (Whittall et al. 2004). AFLP markers allowed to identify some hybrid individuals of Salix $\times$ rubens that were morphologically identical to one of the parental species Salix fragilis (Beismann et al. 1997).

\section{MATERIAL AND METHODS}

\section{Plant material}

Young leaves from specimens morphologically identified a priori as putative hybrids Elymus $\times$ mucronatus nvar. mucronatus (14 individuals), E. ×mucronatus nvar. tesquicolus (5 individuals) and presumable parental species $E$. repens (14 individuals) and E. hispidus (15 individuals) were sampled from two localities where they grew together: Smoniowice (Małopolska Upland, S Poland) and Kielce (Kielce-Sandomierz Upland, S Poland) (Table 1). As the plants are strongly rhizomatous, individuals located ca. 6 $\mathrm{m}$ distant from each other were collected to avoid sampling from the same clone. Hybrid identification was based on their combination of parental morphological characters that were identified by Prokudin and Druleva $(1971,1972)$ and Szczepaniak (2003b) as the character set distinguishing two hybrid-origin taxa. Voucher specimens were deposited in the herbarium of the W. Szafer Institute of Botany, Polish Academy of Sciences, in Cracow (KRAM).

\section{Pollen fertility}

Specimens of Elymus repens (5 individuals), E. hispidus (7 individuals) and $E$. $\times$ mucronatus (15 individuals) were tested for the pollen fertility status using the acetic orcein staining method (Table 2). Spikes of these species were collected from the locality in Smoniowice, and preserved in $70 \%$ ethanol solution. Mature anthers from one or two florets from the middle spikelet of the spike were removed onto a microscopic glass slide and macerated in a drop of aceto orcein stain to release pollen grains.

To determine pollen fertility, 300-400 grains were evaluated per individual, and darkly, well-stained pollen grains were recorded as fertile and viable, whereas unstained, very lightly stained or shrunken ones were considered as sterile or non-viable. Pollen fertility was calculated by dividing the number of viable pollen grains by the total number of grains counted in the field of view and averaging them for all the plants in that species. Pollen quality was expressed as the percentage of viable grains detected in each species.

TABLE 2. Comparison of pollen fertility between putative parental species, Elymus repens, E. hispidus and hybrid E. ×mucronatus from population from Smoniowice. $N$ - number of examined plants. Number of sterile hybrids and with very low fertility ranged from 0 to $5 \%$ in bracket.

\begin{tabular}{lccc}
\hline \multirow{2}{*}{ Taxa } & $\mathrm{N}$ & \multicolumn{2}{c}{ Pollen fertility percentage } \\
\cline { 3 - 4 } & & Range & Mean \pm S.D. \\
\hline Elymus repens & 5 & $78.72-97.26$ & $88.05 \pm 6.71$ \\
Elymus hispidus & 7 & $21.33-95.93$ & $80.26 \pm 26.34$ \\
Elymus $\times$ mucronatus & $12(3)$ & $0.00-91.95$ & $59.50 \pm 37.73$ \\
\hline
\end{tabular}

\section{AFLP analysis}

Genetic diversity of Elymus repens, E. hispidus and E. ×mucronatus was assessed using Amplified Fragment Length Polymorphism (AFLP; Vos et al. 1995). Total genomic DNA was extracted from $50 \mathrm{mg}$ of dried leaf tissue following the DNeasy Plant Mini Kit procedure (Qiagen).

AFLP fingerprinting was performed according to the modifications of Bednarek et al. (1999). Genomic DNA was digested with two restriction enzymes (EcoRI and $M s e I)$. The resulting EcoRI and MseI sticky ended fragments were ligated to the complementary ends of synthetic adaptors. The PCR preselective amplification was performed using primers with a single selective nucleotide: Eco$\mathrm{RI}+\mathrm{A}$ and $M s e \mathrm{I}+\mathrm{C}$. The final selective amplification was performed using seven selective primers pairs: E-AGT/MCTG, E-AGT/M-CTT, E-AGG/M-CGG, E-AGG/M-CAG, E-ACA/M-CGC, E-ACA/M-CAA and E-ACC/M-CCA, which revealed the greatest number of polymorphic, wellseparated, and reproducible bands. The EcoRI primer in these reactions was labelled with ${ }^{32} \mathrm{P}$. Amplified fragments were separated on $7 \%$ polyacrylamide gels and exposed to $\mathrm{X}$-ray film (Kodak) at $-30^{\circ} \mathrm{C}$ for $1-2$ days.

\section{Data analysis}

For the genetic diversity analysis, AFLP fragments were scored as present (1) or absent (0), and used as a raw data matrix. Total number of amplified fragments, the number of polymorphic loci, and the percentage of polymorphic loci were individually scored for parental and hybrid taxa (Table 3). The number of unique, species-specific and hybrid-specific AFLP fragments (e.g. whether they were present with $100 \%$ frequency in all the samples of one taxon and absent in all the samples of other taxa) were next detected within Elymus repens, E. hispidus and E. ×mucronatus. The fragments shared between the assumed parental species were identified. Inherited patterns of parental AFLP fragments in the putative hybrids were analyzed in different combinations as: (1) number of shared AFLP fragments between either the supposed parental species and the hybrids (without the second parent) for confirmation of parental contribution in hybridization of E. repens and E. hispidus, respectively, (2) number of exclusively shared species-specific AFLP fragments between E. repens and all the hybrid specimens, and between E. hispidus and all the hybrid specimens, for the detection of the potential introgression direction (Table 4).

Genetic similarities among individuals of Elymus repens, E. hispidus and E. ×mucronatus were calculated for all AFLP phenotypes data and using the method developed by Nei and Li (1979). Genetic parameters were computed using POPGENE vers. 1.31 (Yeh et al. 1997).

The clustering UPGMA method (unweighted pair group method average) was applied using the matrix of Nei and Li's similarity coefficients (Nei and Li 1979) with the NTSYS-pc software vers. $2.02 \mathrm{j}$ and was performed (Rohlf 1993).

Principal coordinates analysis (PCoA, Gower 1966) was based on Euclidean distances matrix and was performed using the MVSP ver. 3.1 (Kovach 1999). UPGMA and PCoA were used to resolve patterns of variation and relationships among and within taxa.

The hierarchical genetic structure (between the carried out and hybrid taxa, among the accessions and within the 
TABLE 3. Selected seven primer combinations and polymorphism rates for AFLP analysis of the 3 accessions of Elymus repens, 4 accessions of E. hispidus and 4 accessions of hybrids E. ×mucronatus.

\begin{tabular}{|c|c|c|c|c|c|c|c|c|}
\hline \multirow{3}{*}{$\begin{array}{l}\text { Primers combinations } \\
\text { EcoRI.../MseI... }\end{array}$} & \multicolumn{2}{|c|}{ All accessions } & \multicolumn{2}{|c|}{ Elymus repens } & \multicolumn{2}{|c|}{ Elymus hispidus } & \multicolumn{2}{|c|}{ Elymus $\times$ mucronatus } \\
\hline & Total & Polymorphic & Total & Polymorphic & Total & Polymorphic & Total & Polymorphic \\
\hline & \multicolumn{2}{|c|}{ fragments } & \multicolumn{2}{|c|}{ fragments } & \multicolumn{2}{|c|}{ fragments } & \multicolumn{2}{|c|}{ fragments } \\
\hline AGT/CTG & 66 & 53 & 46 & 16 & 48 & 17 & 49 & 16 \\
\hline AGG/CGG & 77 & 64 & 53 & 21 & 54 & 14 & 57 & 24 \\
\hline $\mathrm{ACA} / \mathrm{CGC}$ & 74 & 66 & 66 & 40 & 53 & 24 & 56 & 36 \\
\hline $\mathrm{ACA} / \mathrm{CAA}$ & 85 & 57 & 67 & 17 & 60 & 4 & 63 & 13 \\
\hline AGG/CAG & 51 & 16 & 45 & 2 & 47 & 7 & 49 & 9 \\
\hline AGT/CTT & 57 & 25 & 48 & 2 & 46 & 5 & 48 & 7 \\
\hline $\mathrm{ACC} / \mathrm{CCA}$ & 67 & 19 & 59 & 3 & 57 & 3 & 58 & 5 \\
\hline Total & 477 & $300(62.89 \%)$ & 384 & $101(26.30 \%)$ & 365 & $74(20.27 \%)$ & 380 & $110(28.95 \%)$ \\
\hline Mean & 68.11 & 42.86 & 54.86 & 14.43 & 52.14 & 10.57 & 54.29 & 15.71 \\
\hline SD & 11.70 & 21.97 & 9.26 & 13.82 & 5.34 & 7.93 & 5.71 & 10.98 \\
\hline
\end{tabular}

TABLE 4. Number of unique, species-specific AFLP fragments for each Elymus repens, E. hispidus and E. ×mucronatus species and number of shared AFLP fragments between putative parental species and hybrids.

\begin{tabular}{|c|c|c|c|c|c|c|c|c|}
\hline $\begin{array}{l}\text { Primers combinations } \\
\text { EcoRI.../MseI... }\end{array}$ & $\begin{array}{c}\text { No. of species- } \\
\text {-specific } \\
\text { AFLP } \\
\text { fragments } \\
\text { for E. repens }\end{array}$ & $\begin{array}{l}\text { No. of species- } \\
\text {-specific } \\
\text { AFLP } \\
\text { fragments } \\
\text { for E. hispidus }\end{array}$ & $\begin{array}{c}\text { No. of hybrid- } \\
\text {-specific } \\
\text { AFLP } \\
\text { fragments }\end{array}$ & $\begin{array}{c}\text { No. of shared } \\
\text { AFLP } \\
\text { fragments } \\
\text { between } \\
\text { E. repens and } \\
\text { E. hispidus } \\
\text { (without } \\
\text { hybrids) }\end{array}$ & $\begin{array}{l}\text { No. of shared } \\
\text { AFLP } \\
\text { fragments } \\
\text { between } \\
\text { E. repens and } \\
\text { hybrids } \\
\text { (without } \\
\text { E. hispidus) }\end{array}$ & $\begin{array}{l}\text { No. of shared } \\
\text { AFLP } \\
\text { fragments } \\
\text { between } \\
\text { E. hispidus } \\
\text { and hybrids } \\
\text { (without } \\
\text { E. repens) }\end{array}$ & $\begin{array}{l}\text { No. of species- } \\
\text {-specific } \\
\text { AFLP } \\
\text { fragments } \\
\text { exclusively } \\
\text { shared } \\
\text { between } \\
\text { E. repens and } \\
\text { hybrids } \\
\text { (with 100\% } \\
\text { frequency) }\end{array}$ & $\begin{array}{c}\text { No. of species- } \\
\text {-specific } \\
\text { AFLP } \\
\text { fragments } \\
\text { exclusively } \\
\text { shared } \\
\text { between } \\
\text { E. hispidus } \\
\text { and hybrids } \\
\text { (with } 100 \% \\
\text { frequency) }\end{array}$ \\
\hline AGT/CTG & 11 & 13 & 0 & 13 & 15 & 31 & 0 & 13 \\
\hline AGG/CGG & 14 & 15 & 0 & 13 & 14 & 32 & 0 & 11 \\
\hline ACA/CGC & 4 & 2 & 0 & 8 & 8 & 18 & 0 & 1 \\
\hline ACA/CAA & 16 & 14 & 0 & 28 & 36 & 49 & 0 & 13 \\
\hline AGG/CAG & 2 & 5 & 0 & 35 & 35 & 40 & 0 & 5 \\
\hline AGT/CTT & 10 & 7 & 0 & 32 & 32 & 41 & 0 & 7 \\
\hline $\mathrm{ACC} / \mathrm{CCA}$ & 8 & 5 & 0 & 48 & 47 & 53 & 0 & 4 \\
\hline Total & 65 & 61 & 0 & 177 & 187 & 264 & 0 & 54 \\
\hline Mean & 9.29 & 8.71 & 0 & 25.29 & 26.71 & 37.71 & 0 & 7.71 \\
\hline $\mathrm{SD}$ & 5.06 & 5.19 & 0 & 14.51 & 14.40 & 11.86 & 0 & 4.72 \\
\hline
\end{tabular}

accessions) was assessed using analysis of molecular variance (AMOVA). AMOVA is based on the nonparametric permutation approach (Excoffier et al. 1992) and on pairwise squared Euclidean distances between AFLP phenotypes. AMOVAs were performed using ARLEQUIN version 2.0 (Schneider et al. 2000.

\section{RESULTS}

\section{Fertility of the putative parental species and the hybrids}

Pollen fertility results obtained using the aceto orcein stain method are given in Table 2. Average pollen viability was comparable for the parental species and ranged from $80.26 \%$ ( \pm 26.34$)$ for Elymus hispidus to $88.05 \%$ ( \pm 6.71 ) for $E$. repens. It was interesting to note that $E$. hispidus showed a wide range of pollen viability varying from 21.33 to $95.93 \%$. However, only one specimen, morphologically defined as E. hispidus var. hispidus, was low fertile, which suggests its hybrid origin.

Pollen fertility among the hybrids was highly variable and ranged from complete sterility $0 \%$ to high fertility $91.95 \%$ (average $59.50 \pm 37.73$ ). One of E. ×mucronatus specimens was sterile and two specimens had about $5 \%$ fertile pollen grains. Two hybrids showed pollen fertility of less than $50 \%$, while the other seven specimens had about $80 \%$ fertile pollen grains. This variation of fertility degree indicates different origins of hybrids that can be F1 individuals (most probably sterile in this case) or backcross hybrids (they exhibit higher fertility), arisen by mating with one or with both parental species or among hybrids.

AFLP polymorphism in the parental species, Elymus repens and $E$. hispidus, and in hybrids

Seven AFLP primer combinations show a total of 477 clearly identifiable and reproducible bands of all the assumed 
progenitors Elymus repens and E. hispidus and the putative hybrid progenies between them. Of these AFLP bands, 300 $(62.89 \%)$ were polymorphic and $177(37.11 \%)$ bands were common to all the samples analyzed (Table 3 ). On the average, 42.86 polymorphic AFLP fragments were detected per primer pair. For 14 individuals of E. repens and 15 individuals of E. hispidus, 101 (26.30\%) and $74(20.27 \%)$ polymorphic bands were detected, respectively. However, putative hybrid-derived samples were more genetically diversified than the putative parents, displaying a total of 110 (28.95\%) polymorphic AFLP fragments (Table 3).

The number of legible species-specific fragments produced with each primer pair is given in Table 4 . The analysis of the data obtained from scoring the monomorphic species-specific fragments (which were exclusively present in a given taxon) shows 65 fragments unique to Elymus repens and a comparable number of 61 fragments unique to E. hispidus. The parental species, without the hybrids, shared 177 (37.11\%) AFLP fragments. No exclusive hybridspecific fragments existed in any of the 19 individuals of E. xmucronatus.

Inheritance of the parental banding patterns in the putative hybrids is given in Table 4. A total of $187(48.70 \%)$ Elymus repens and 264 (72.33\%) of E. hispidus AFLP fragments were found in the hybrids. Furthermore, the analysis of species-specific fragments shared exclusively between $E$. repens and hybrid specimens and between $E$. $h i$ spidus and the hybrids revealed no common fragments in the former and 54 AFLP fragments in the later case, respectively.

\section{Cluster analysis}

Cluster analysis (UPGMA) based on the matrix of genetic similarities among the parents and putative hybrids re- sulted in a dendrogram that clearly distinguished two main groups corresponding to Elymus repens and E. hispidus with hybrids (Fig. 1). These two clusters were identified at the $67 \%$ similarity level. In the dendrogram, individuals of the putative hybrids (E. ×mucronatus nvar. mucronatus M1, M2, M3, and E. ×mucronatus nvar. tesquicolus - Te) were grouped with $E$. hispidus individuals (E. hispidus var. hispidus - H, H3, and E. hispidus var. villosus - V, V3) and formed one cluster. Some hybrid derivatives (M1 and M2) grouped within the main cluster formed subclusters between their parents, and were somewhat genetically distinct from E. hispidus and other hybrids, which may suggest more advanced hybridization and the beginning of the hybrid stabilization process.

The analysis shows that individuals of Elymus hispidus in both varieties and hybrids collected in the same habitat were more similar to each other than to the individuals collected at the other locality. Individuals of E. hispidus var. hispidus (H3), var. villosus (V3) and E. ×mucronatus nvar. mucronatus (M3) from Kielce are clustered together (Fig. 1). Likewise, the specimens of E. hispidus var. hispidus $(\mathrm{H})$, var. villosus (V) and E. ×mucronatus nvar. tesquicolus (Te) from Smoniowice are grouped together, which may indicate a gene flow within the species and among the hybrids within one habitat. Furthermore, specimens of E. repens var. repens (R2) appear to have a closer genetic relationship with $E$. repens var. aristatus (R1) from the same habitat in Smoniowice than with E. repens var. repens (R3) from the locality in Kielce.

\section{Principal coordinates analysis}

PCoA results are on the whole similar to those of UPGMA, and clearly show a genetic distinction of Elymus repens from E. hispidus and the hybrids (Fig. 2). The first th-

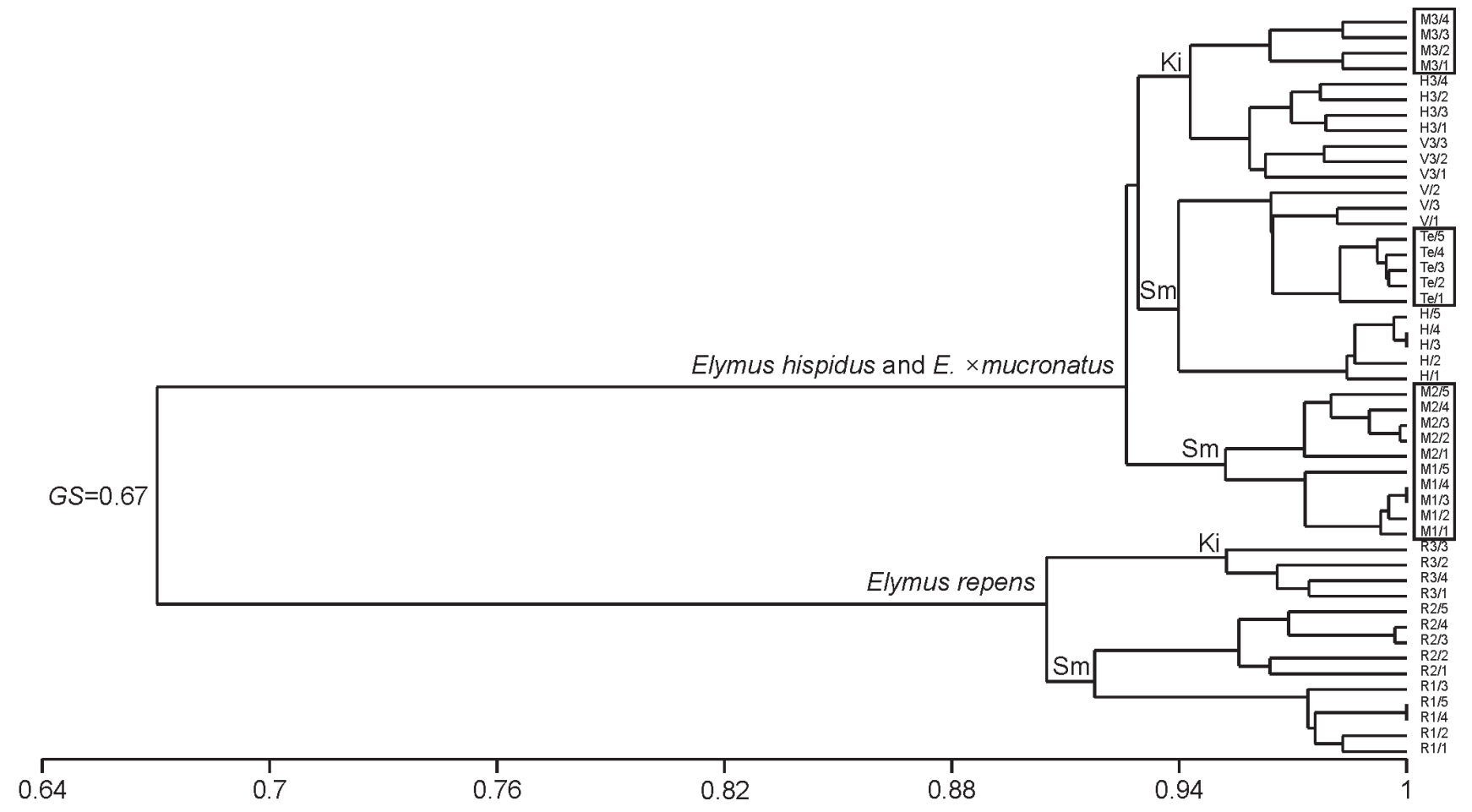

Fig. 1. UPGMA dendrogram of Elymus repens (R), E. hispidus (H, V) and E. ×mucronatus (M, Te) individuals from two localities: Smoniowice (Sm) and Kielce (Ki), based on Nei and Li's similarity coefficients $(G S)$ and 477 AFLP fragments. Details of accessions labels correspond to the abbreviations given in Table 1. All the hybrid individuals were marked by frames on the dendrogram. 

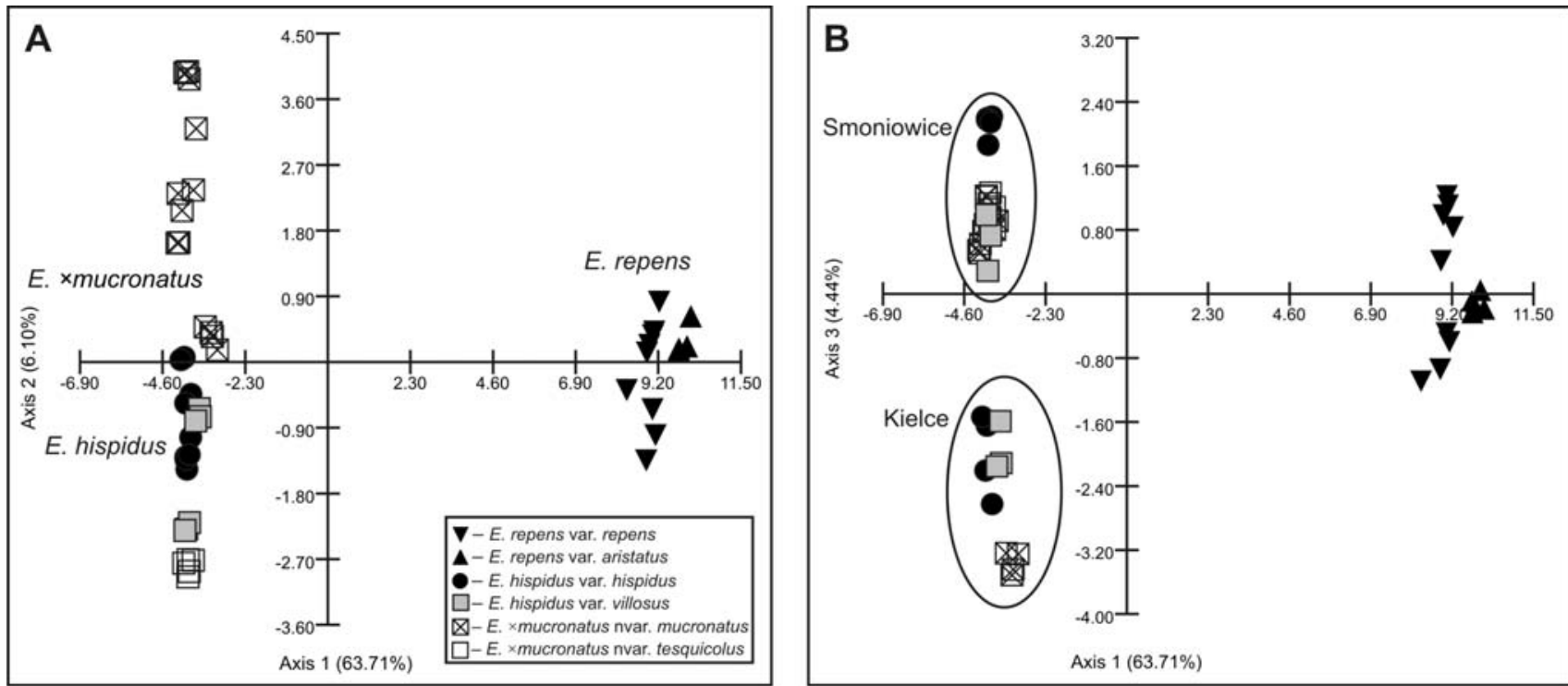

Fig. 2. Principal coordinates analysis (PCoA) of individuals of the parental species Elymus repens and E. hispidus and their hybrids E. $\times$ mucronatus collected in two localities: Smoniowice and Kielce, based on AFLP data. Plot of principal coordinate one against two (A) and three (B).

ree axes accounted for $74.25 \%$ of the total genetic variation (63.71\% for axis $1,6.10 \%$ for axis 2 , and $4.44 \%$ for axis 3 ). The second axis separates some E. ×mucronatus nvar. mucronatus specimens most clearly (Fig. 2A), similarly to UPGMA, whereas the third axis strongly groups specimens of $E$. hispidus and the hybrids from individual habitats in Smoniowice and Kielce (Fig. 2B).

As shown by the analysis of AFLP polymorphism of studied taxa and UPGMA and PCoA results, the hybrids appear genetically closer to Elymus hispidus than to E. repens. This is summarized by average genetic similarities between these groups of $92 \%$ for the hybrids and E. hispi$d u s$, and $65 \%$ for hybrids and E. repens. The parental species are less similar to each other than $E$. ×mucronatus to E. hispidus (Table 5). This high genetic similarity of the hybrids to E. hispidus, can be formed by unidirectional backcrossing of partially fertile hybrid individuals with one parental species E. hispidus.

TABLE 5. Genetic similarity $(G S)$ within and between individuals of Elymus repens, E. hispidus and E. ×mucronatus hybrids based on Nei and Li's similarity coefficients (Nei and Li 1979).

\begin{tabular}{lcc}
\hline \multirow{2}{*}{ Species } & \multicolumn{2}{c}{ Nei and Li's similarity coefficient } \\
\cline { 2 - 3 } & Range & Mean \\
\hline E. repens & $0.881-0.983$ & 0.936 \\
E. hispidus & $0.928-0.997$ & 0.954 \\
E. repens vs. E. hispidus & $0.630-0.715$ & 0.640 \\
E. repens vs. hybrids & $0.631-0.702$ & 0.648 \\
E. hispidus vs. hybrids & $0.904-0.957$ & 0.919 \\
\hline
\end{tabular}

Significant genetic diversity $(68.21 \%, p<0.006)$ between parental species Elymus repens, E. hispidus and hybrids E. Xmucronatus was confirmed by AMOVA results based on the grouping of the specimens into particular taxa obtained in UPGMA and PCoA (Table 6). Genetic variation between accessions of individual taxa was also significant $(21.68 \%, p<0.001)$ while the genetic variation within accessions was not statistically significant.

\section{DISCUSSION}

The putative parental species Elymus repens and E. hispidus frequently co-occur in natural and disturbed habitats (present authors' field observations). Some specimens are readily identifiable as "pure" species in such populations while others are morphologically intermediate, clearly having characters of both parental species. Other intermediate plants cannot be identified with certainty because of their great similarity to either E. hispidus or E. repens. Such two populations were studied in an attempt to determine whether interspecific hybridization occurred between $E$. repens and $E$. hispidus or whether E. hispidus exhibited great morphological variation.

Results of previous statistical analyses of some morphological characters such as the lengths of spikes, spikelets, glumes and lemmas did not sufficiently affirm the hybrid origin of Elytrigia $\times$ mucronata and Elytrigia $\times$ tesquicola (Prokudin and Druleva 1971, 1972). Nonetheless, a detailed biosystematic study of Elymus repens and E. hispidus confirmed the occurrence of natural hybrids among those spe-

TABLE 6. Summary results of the analysis of molecular variance (AMOVA) based on AFLP data. Plants represented 3 accessions of Elymus repens, 4 accessions of E. hispidus and 4 accessions of hybrids E. ×mucronatus. Levels of significance are based on 1023 iteration steps.

\begin{tabular}{lcccr}
\hline Level of variation & d.f. & Variance components & Percentage of variation & Fixation index \\
\hline Among taxa & 2 & 51.10 & 68.21 & $<$ \\
Among accessions within taxa & 8 & 16.24 & 21.68 & $\mathrm{~F}_{\mathrm{CT}}=0.682$ \\
Within accessions & 37 & 7.57 & 10.11 & $\mathrm{~F}_{\mathrm{SC}}=0.682$ \\
\hline Total & 47 & 74.91 & 100 & $\mathrm{~F}_{\mathrm{ST}}=0.899$ \\
\hline
\end{tabular}


cies in Poland (Szczepaniak 2002b, 2003b). Hybrid progenies combine both progenitors' morphological, anatomical and genetic characters, and are clearly distinguishable in multivariate statistical analyses (Szczepaniak 2003b).

Pollen quality evaluation and AFLP analysis indicate hybridization between Elymus repens and E. hispidus. However, the question arises whether we deal with F1 hybrids and/or next generations of hybrids within mixed populations; in other words, how far a population has progressed from early hybridization (F1 only) stages to a well-established hybrid swarm.

\section{Pollen fertility: implications for hybridization stages}

On the whole, average pollen fertility of hybrids Elymus $\times$ mucronatus is relatively high, and about $50 \%$ of pollen grain sets are viable and able to pollinate. At the same time, pollen fertility among the hybrid individuals is extremely varied and ranges from complete sterility of $0 \%$ to nearly complete fertility of $90 \%$, sometimes higher than in the parental species (Table 2). Different stages of hybridization can coexist in populations where parental species and hybrids co-occur. The early hybridization stage indicates high sterile of F1 hybrid individuals (25\% of analyzed plants). Sterility of $\mathrm{F} 1$ hybrids between $E$. repens and E. hispidus was also confirmed by Assadi (1995), who studied meiosis in a plant with $2 n=42$.

Our results show that the populations of Elymus repens, E. hispidus and hybrids still progress from early hybridization stages (F1) to a well-established hybrid swarm, that is an advanced hybridization stage. A hybrid swarm is a population of individuals that are all hybrids by a varying number of generations of backcrossing with parental species and by mating among hybrids (Allendorf et al. 2001). Low viable F1 hybrids of E. ×mucronatus are unlikely to mate among themselves. However, backcrossing with either of the high fertility parental species, E. repens or E. hispidus, is more probable.

Introgression effects blur genetic integrity of parental taxa by the gene flow between their populations. Hybrids, backcrossing with either of the parents, are a good platform for the intertaxa gene flow. Assadi and Runemark (1995) obtained artificial F1 hybrids between Elymus repens and E. hispidus. The shape of the hybrid's spike and the hairiness of glumes and the lemma were similar to those of E. hispidus. The anthers were released and were partly dehiscent, and the pollen fertility was $20 \%$. The authors emphasize high polyploidy of both parents. Therefore, it is not unexpected to find $20 \%$ fertile pollen in the hybrids. Since hybrids between $E$. repens and E. hispidus are relatively common in the field and propagate vegetatively by rhizomes, at least some gene flow via backcrossing to the parents can be expected. In our study, average pollen fertility of hybrids is higher than that found by Assadi and Runemark (1995), which can be caused by advanced hybridization and a greater frequency of introgressants of following generations than that of F1 hybrids in the populations studied. Fertility is one of the factors stabilizing hybrid-derived individuals and in effect gives rise to new lineages of species or even genera. A single, even partially fertile, hybrid individual may suffice as a progenitor of a new species. However, that tiny fraction, summed over thousands of generations, can make a considerable impact in evolutionary time (Ellstrand et al. 1996).
Genetic evidence for hybridization between Elymus repens and Elymus hispidus

Significant genetic differences between the parental species Elymus repens and E. hispidus were proved by the AMOVA performed in our study. In comparison with the level of intraspecific genetic variation determined in a previous study (Szczepaniak and Cieślak 2003), a similar level of polymorphic loci within E. repens (104 loci vs 101 loci) and a considerably lower number of polymorphic loci within E. hispidus (167 loci vs 74 loci) were detected in the present research. Such a decrease in intraspecific genetic variation of E. hispidus can be caused by putative interspecific hybridization and the loss of part of the parental genetic pool for hybrid genetic variation.

It is apparent from the AFLP analyses that Elymus repens and E. hispidus are progenitors of the hybrid taxon Elymus $\times$ mucronatus. AFLP data show a number of unique fragments of the parental species, but we did not find fragments specific to hybrid taxa (Table 4). Parental AFLP fragments inherited from both parents were present in all of the hybrid individuals. The lack of the accumulation of genetic changes in the hybrids could be explained by relatively recent origin of the hybrids. In this case, micro-evolutionary processes continue in the local habitats. A relatively recent hybrid-derived taxon is unlikely to have unique alleles, and, for biparentally inherited fragments, patterns would be likely to be an additive combination of the two parents (Goldman et al. 2004).

Although cluster analysis based on the AFLP data, can relatively easily distinguish Elymus ×mucronatus from both parental species, the percentage of similarity with the parental species was very high $(65 \%$ with E. repens and as much as $92 \%$ with E. hispidus). This provides further evidence for a recent origin of this hybrid species. Does such a high genetic similarity between E. hispidus and hybrids suggest that these putative hybrid individuals can be elements of the variability range of E. hispidus and locate them at its extreme limit? Such a genetic similarity of individuals of different taxa indicates a weakness of reproductive barriers and the local gene flow between parental species and hybrids. Previous studies of Prokudin and Druleva (1971, 1972) prove that flowering times and rhythms in two putative parental species coincide, which confirms the possibility of their crossing. All of the taxa studied are hexaploids with 2n=42 (Mizianty et al. 2001). Meiosis in Elytrigia $\times$ mucronata proceeds normally without any disturbances (Prokudin and Druleva 1971). Disturbances found in the reductive division, e.g. in the metaphase and anaphase of the first division, in Elytrigia $\times$ tesquicola indicate its hybrid derivation (Prokudin and Druleva 1972). Such a relatively regular meiosis in hybrids suggests that their progenitors, E. repens and E. hispidus, are two phylogenetically similar hexaploid taxa.

AFLP data show that most hybrids grouped in their own intermediate cluster, which proves their certain genetic distinction and may indicate the beginning of the hybrid stabilization process and speciation (Fig. 1). The genetic results confirm the evidence of biometric analyses of morphological characters set, which clearly distinguishes Elymus $\times$ mucronatus from the parental species (Szczepaniak 2002b, 2003b). Individuals of E. ×mucronatus marked as M1 were characterized by more or less truncate glumes, 
hairless, sharp lemmas with long awns and ciliate margins of leaves sheaths. Individuals of M2 differ from M1 by the sharply pointed lemmas or lemmas with short awns. Some of these hybrids were fertile; however, vegetative propagation has made a major contribution to the establishment and persistence of $E$. ×mucronatus.

Other hybrid individuals are genetically relatively similar to Elymus hispidus or E. repens, which resulted in a mosaic of morphological parental characters. The results show that the taxonomic status of Elytrigia $\times$ mucronata and Elytrigia $\times$ tesquicola may be lowered from hybrid species to intraspecific varieties of Elymus ×mucronatus. Individuals of E. $\times$ mucronatus nvar. mucronatus and nvar. tesquicolus display a continuum of morphological variation (Szczepaniak 2003b), differ only by the degree of hairiness of glumes and lemmas, and are not genetically distinct. A similar level of intraspecific genetic and morphological differences were affirmed within the parental species E. hispidus by recognition varieties; var. hispidus and var. villosus (Assadi 1998; Szczepaniak 2003b) and within E. repens; var. repens, var. aristatus and var. subulatus (Szczepaniak 2003a). Morphological varieties of E. hispidus and E. repens are not reproductively isolated and form fertile hybrids.

AFLP data analyses display that the hybrids are closer to Elymus hispidus than to E. repens and suggest unidirectional introgressive hybridization between the species. In UPGMA and PCoA, all E. repens individuals form their own group, regardless of the occurrence site of particular specimens (Figs 1 and 2). E. hispidus and hybrids cluster together, although within subclusters that correspond to individual localities, Smoniowice and Kielce (Fig. 2). Asymmetrical introgression when hybrids contained more nuclear markers from either parental taxa is partially related to the frequency of these parental taxa in individual populations (Burgess et al. 2005). In the populations studied, E. hispidus occurred in great abundance throughout the habitat, whereas $E$. repens was found in a much smaller number of individuals only on the habitat edges. It appears that E. hispidus occurs primarily in the habitats studied, on the loess in Smoniowice and calcareous soils in Kielce. E. hispidus is adapted to a narrow range of environmental conditions and displays rather low phenotypic plasticity (Szczepaniak 2001; Mahelka 2006). The disturbance of agricultural activities in habitats on the field margins (in Smoniowice) and in the quarry neighbouring on a meadow (in Kielce) caused the disappearance of the more susceptible parental species $E$. hispidus and the spread of the better adapted hybrid specimens. Individuals of E. ×mucronatus are very vigorous and robust, and they have a greater potential to colonize disturbed habitats. This confirms the hybrids' dominant position in the populations studied and explains the difficulty in finding "pure" specimens of E. hispidus (present authors' field observations).

Hybridization and introgression can produce shifts in morphology and ecological tolerance, and thus greatly increase the potential of hybrids or introgressants for adaptation in habitats other than optimum for progenitors. As stated, ecological marginal populations of Carex curvula are mainly composed of individuals with genotypes resulting from introgressive hybridization. Genotype integrity of this species is maintained in optimal habitats, while introgressed individuals are favoured in marginal habitats (Choler et al. 2004). Studies on flooding tolerance of Elytrigia repens,
E. intermedia and their hybrids have shown that hybridization may lead to the enrichment of hybrids' gene pools with genes responsible for the survival of the parental species under extreme conditions (Mahelka 2006).

\section{CONCLUSIONS}

AFLP analyses and the level of pollen fertility unambiguously support the hybrid origin of Elymus $\times$ mucronatus. All of the AFLP fragments of the hybrid taxon were derived from the putative parents; there were no hybrid-specific bands. F1 hybrids not detected morphologically were distinguished from the parental species and backcross hybrids. Unidirectional introgression causes genetic swamping of E. hispidus by the hybrid swarm in the populations studied. E. repens retains its own genetic integrity to a greater degree than E. hispidus, additionally confirmed by AFLP data.

Individuals of the parental species are difficult to find in the habitats studied, and the populations are composed of very vigorous hybrids that spread by extensive long, creeping rhizomes. Some Elymus $\times$ mucronatus individuals yielded fully developed seeds, observed in natural habitats, also confirming backcrossing to the parental species, or indicating some degree of self-pollination. Therefore, E. ×mucronatus fulfils molecular criteria for determining hybrid species (Zhou et al. 2005) and could be potentially self-sustaining. It should be considered as a species with the genetic material that can assort among its specimens in their own genome. Furthermore, morphological characters distinguishing hybrids remain stable in homogeneous growth conditions in the Botanical Garden of the Jagiellonian University (present authors' observations). We propose to consider Elymus $\times$ mucronatus as a new species of hybrid origin in the Polish flora.

The results support the generally expressed viewpoint that generic deliminations within the tribe Triticeae, and especially between Elymus species, are problematic and controversial because of the lack of clear-cut morphological differences and weak genetic barriers among taxa (e.g., Baum et al. 1987; Salomon and Lu 1992; Assadi and Runemark 1995; Barkworth 2000). Brown and Pratt (1960) conclude that hybridization and subsequent introgression have occurred many times and in many places, and are still taking place in the populations of Elymus species, forming introgressant types within individual species. The present results of AFLP analyses support the view that Elymus species, as well as all the Poaceae in a wider context, are predisposed to hybridization, which, among other, affects their enormous evolutionary potential.

\section{ACKNOWLEDGMENTS}

The authors thank Małgorzata Zawada for her technical assistance. The work was supported by the State Committee for Scientific Research (KBN) grant no. 6 P04C 07619.

\section{LITERATURE CITED}

ALLENDORF F.W., LEARY R.F., SPRUELL P., WENBURG J.K. 2001. The problems with hybrids: setting conservation guidelines. Trends Ecol. Evol. 16 (11): 613-622. 
ARNOLD M.L. 1997. Natural hybridization and evolution. Oxford University Press, Oxford, UK, $215 \mathrm{pp}$.

ASSADI M. 1995. Meiotic configuration and chromosome number in some Iranian species of Elymus L. and Agropyron Gaertner (Poaceae, Triticeae). Bot. J. Linn. Soc. 117: 159-168.

ASSADI M. 1998. Biosystematic studies of the Elymus hispidus (Poaceae: Triticeae) group in Iran. Nord. J. Bot. 18: 483-492.

ASSADI M., RUNEMARK H. 1995. Hybridisation, genomic constitution and generic delimitation in Elymus s.l. (Poaceae, Triticeae). Pl. Syst. Evol. 194: 189-205.

BARKWORTH M.E. 2000. Changing perceptions of the Triticeae. In: Grasses: Systematics and Evolution. Jacobs S.W.L. and Everett J. (eds). CSIRO, Melbourne, pp. 110-120.

BAUM B.R., ESTES J.R., GUPTA P.K. 1987. Assessment of the genomic system of classification in the Triticeae. Amer. J. Bot. 74: 1388-1395.

BEDNAREK P.T., CHWEDORZEWSKA K., KRÓLICZAK J., PUCHALSKI J., ZAWADA M. 1999. AFLP molecular markers as a tool for genetic variability studies of rye inbred lines. Biul. Inst. Hod. Aklim. Rośl. 211: 219-227.

BEISMANN H., BARKER J.H.A., KARP A., SPECK T. 1997. AFLP analysis sheds light on distribution of two Salix species and their hybrid along a natural gradient. Mol. Ecol. 6: 989$-993$.

BERCHTOLD G.F., OPIZ P.M. 1836. Oekonomisch-technische Flora Böhmens I/2. J. H. Pospischil, Prag.

BROWN W.V., PRATT G.A. 1960. Hybridization and introgression in the grass genus Elymus. Amer. J. Bot. 47 (8): 669-676.

BURGESS K.S., MORGAN M., DEVERNO L., HUSBAND B.C. 2005. Asymmetrical introgression between two Morus species (M. alba, M. rubra) that differ in abundance. Mol. Ecol. 14 (11): 3471-3483.

CHOLER P., ERSCHBAMER B., TRIBSCH A., GIELLY L., TABERLET P. 2004. Genetic introgression as a potential to widen a species' niche: Insights from alpine Carex curvula. Proc. Natl. Acad. Sci. U.S.A. 101 (1): 171-176.

DIAZ O., SALOMON B., BOTHMER R. VON. 1999. Genetic diversity and structure in populations of Elymus caninus (L.) L., Poaceae. Hereditas 131: 63-74.

ELLSTRAND N.C., WHITKUS R., RIESEBERG L.H. 1996. Distribution of spontaneous plant hybrids. Proc. Natl. Acad. Sci. U.S.A. 93: 5090-5093.

EXCOFFIER L., SMOUSE P.E., QUATTRO J.M. 1992. Analysis of molecular variance inferred from metric distances among DNA haplotypes: application to human mitochondrial DNA restriction data. Genetics 131: 479-491.

GOLDMAN D.H., JANSEN R.K., VAN DEN BERG C., LEITCH I.J., FAY M.F., CHASE M.W. 2004. Molecular and cytological examination of Calopogon (Orchidaceae, Epidendroideae): circumscription, phylogeny, polyploidy, and possible hybrid speciation. Am. J. Bot. 91 (5): 707-723.

GOWER J.C. 1966. Some distance properties of latent root and vector methods used in multivariate analysis. Biometrika 53: 325-328.

GUO Y.P., SAUKEL J., MITTERMAYR R., EHRENDORFER F. 2005. AFLP analyses demonstrate genetic divergence, hybridization, and multiple polyploidization in the evolution of Achillea (Asteraceae-Anthemideae). New Phytol. 166: 273-290.

HEGARTY M.J., HISCOCK S.J. 2005. Hybrid speciation in plants: new insights from molecular studies. New Phytol. 165: 411-423.

HULTÉN E., FRIES M. 1986. Atlas of North European vascular plants. North of the Tropic of Cancer. 1. 498 pp., 3. 1172 pp. Koelz Scientific Books, Königstein.

KOVACH W.L. 1999. MVSP - A multi-variate statistical package for windows, ver. 3.1. Kovach computing Services, Penthraeth.

MAHELKA V., SUDA J., JAROLÍMOVÁ V., TRÁVNÍČEK P., KRAHULEC F. 2005. Genome size discriminates between closely related taxa Elytrigia repens and E. intermedia (Poaceae: Triticeae) and their hybrid. Folia Geobot. 40: 367-384.

MAHELKA V. 2006. Response to flooding intensity in Elytrigia repens, E. intermedia (Poaceae: Triticeae) and their hybrid. Weed Res. 46: 82-90.

MARHOLD K., LIHOVÁ J., PERNÝ M., GRUPE R., NEUFFER B. 2002. Natural hybridization in Cardamine (Brassicaceae) in the Pyrenees: evidence from morphological and molecular data. Bot. J. Lin. Soc. 139: 275-294.

MELDERIS A. 1980. Elymus L. In: Flora Europaea. 5. Alismataceae to Orchidaceae (Monocotyledones). Tutin T.G., Heywood V.H., Burges N.A., Moore D.M., Valentine D.H., Walters S.M., Webb D.A. (eds). Cambridge University Press, Cambridge, pp. 192-198.

MIZIANTY M., FREY L., SZCZEPANIAK M. 2001. The Agropyron-Elymus complex (Poaceae) in Poland: biosystematics. In: Studies on grasess in Poland. Frey L. (ed.). W. Szafer Institute of Botany, Polish Academy of Sciences, Kraków. pp. 25$-77$.

NEI M., LI W.H. 1979. Mathematical model for studying genetic variation in terms of restriction endonucleases. Proc. Nat. Acad. Sci. 76: 5269-5273.

NELSON E.N., TYRL R.J. 1978. Hybridization and introgression between Elymus canadensis and Elymus virginicus (Poaceae). Proc. Okla. Acad. Sci. 58: 32-34.

PROKUDIN YU.N. 1940. Agropyrum tesquicolum Prokudin. In: Flora Republicae Sovieticae Socialisticae Ucrainicae. vol. 2. Bordzilovskii E.I. and Lavrenko E.M. (eds). Vidavnitstvo Akademii Nauk Ukrains'koi RSR, Kiev, pp. 339-340. (In Ukrainian)

PROKUDIN YU.N. 1982. Itogi kompleksnovo biosistematicheskovo izuchenia Elytrigia repens (Poaceae) [The results of composite biosystematical study of Elytrigia repens (Poaceae)]. Bot. Zhurn. 67 (2): 129-139. (in Russian with English summary)

PROKUDIN YU.N., DRULEVA I.V. 1971. Pro gibridnu prirodu piriju zaostrenogo (Elytrigia mucronata (Opiz) Prokudin) [On hybrid nature of Elytrigia mucronata (Opiz) Prokudin]. Ukr. Bot. Zhurn. 28 (6): 712-717. (in Ukrainian with English summary)

PROKUDIN YU.N., DRULEVA I.V. 1972. O gibridnoji prirode pyreja stepnogo (Elytrigia tesquicola Prokudin). Bot. Zhurn. 57 (5): 495-500. (in Russian)

RIESEBERG L.H. 1995. The role of hybridization in evolution: old wine in new skins. Amer. J. Bot. 82 (7): 944-953.

ROHLF F.J. 1993. NTSYS-pc. Numerical taxonomy and multivariate analysis system version $2.02 \mathrm{j}$. Applied Biostatistics Inc., New York.

SALOMON B., LU B.-R. 1992. Genomic groups, morphology, and sectional delimitation in Eurasian Elymus (Poaceae, Triticeae). Pl. Syst. Evol. 180: 1-13.

SCHNEIDER S., ROESSLI D., EXCOFFIER L. 2000. Arlequin ver. 2.000: A software for population genetic data analysis. Genetic and Biometry Laboratory, University of Geneva, Switzerland (http://www.lgb.unige.ch/arlequin/).

SZCZEPANIAK M. 2001. The Agropyron-Elymus (Poaceae) complex in Poland: occurrence of the Elymus hispidus subsp. hispidus and subsp. barbulatus. In: Studies on grasess in Poland. Frey L. (ed.). W. Szafer Institute of Botany, Polish Academy of Sciences, Kraków, pp. 177-193.

SZCZEPANIAK M. 2002a. Morphological variability of Polish populations of Elymus repens from various habitats - preliminary report. Ecological Questions 2: 159-168.

SZCZEPANIAK M. 2002b. Biosystematyka Elymus repens (L.) Gould i Elymus hispidus (Opiz) Melderis w Polsce [Biosystematics of Elymus repens (L.) Gould and Elymus hispidus (Opiz) Melderis in Poland]. Mscr. of PhD Thesis, W. Szafer Institute of Botany, Polish Academy of Sciences, Kraków, 181 pp. (in Polish) 
SZCZEPANIAK M. 2003a. Krytyczne studia taksonomiczne nad Elymus repens (L.) Gould [The taxonomic studies of Elymus repens (L.) Gould]. In: Zastosowania metod statystycznych w badaniach naukowych II [Application of statistic methods in scientific studies]. StatSoft Polska. Kraków, pp. 65-73. (in Polish)

SZCZEPANIAK M. 2003b. Zmienność morfologiczna Elymus hispidus (Opiz) Melderis [Morphological variation of Elymus hispidus (Opiz) Melderis]. In: Zastosowania metod statystycznych w badaniach naukowych II [Application of statistic methods in scientific studies]. StatSoft Polska. Kraków, pp. 361370. (in Polish)

SZCZEPANIAK M., CIEŚLAK E., BEDNAREK P.T. 2002. Morphological and AFLP variation of Elymus repens (L.) Gould (Poaceae). Cell. Mol. Biol. Letters 7 (2A): 547-558.

SZCZEPANIAK M., CIEŚLAK E. 2003. Assessment of genetic variation in Elymus repens and E. hispidus using AFLP markers and its implications for intraspecific taxonomy. In: Problems of grass biology. Frey L. (ed.). W. Szafer Institute of Botany, Polish Academy of Sciences, Kraków, pp. 271-286.

TEO L.L., KIEW R., SET O., LEE S.K., GAN Y.Y. 2002. Hybrid status of kuwini, Mangifera odorata Griff. (Anacardiaceae) verified by amplified fragment length polymorphism. Mol. Ecol. 11: 1465-1469.
TSVELEV N.N. 1976. Zlaki SSSR [Grasses of the USSR]. Izdatel'stvo Nauka, Leningrad, 788 pp. (In Russian).

VOS P., HOGERS R., BLEEKER M., REIJANS M., VAN DE LEE T., HORNES M., FRIJTERS A., POT J., PELEMAN J., KUIPER M., ZABEAU M. 1995. AFLP: a new technique for DNA fingerprinting. Nucl. Acids Res. 23: 4407-4414.

WHITTALL J.B., HELLQUIST C.B., SCHNEIDER E.L., HODGES S.A. 2004. Cryptic species in an endangered pondweed community (Potamogeton, Potamogetonaceae) revealed by AFLP markers. Am. J. Bot. 91 (12): 2022-2029.

WISSEMANN V. 2005. Evolution by hybridisation. The influence of reticulate evolution on biosymmetrical patterns and processes in plants. Theory in Biosciences 123 (3): 223-233.

YEH F.C., YANG R.C., BOYLE T.B.J., YE Z.H., MAO J.X. 1997. Popgene, the user-friendly shareware for population genetic analysis. Molecular Biology and Biotechnology Center, University of Alberta, Edmonton, Alberta, Canada (http://www.ualberta.ca/ fyeh/index.htm).

ZHOU R., SHI S., WU C.-I. 2005. Molecular criteria for determining new hybrid species - An application to the Sonneratia hybrids. Mol. Phyl. Evol. 35: 595-601. 